\title{
PERBANDINGAN LATIHAN OTOT ISOTONIK DAN ISOMETRIK TERHADAP PENINGKATAN KEKUATAN OTOT FLEXOR ELBOW PADA MAHASISWA PROGRAM STUDI ILMU KEOLAHRAGAAN ANGKATAN 2015 UNIVERSITAS NEGERI JAKARTA
}

\author{
Randika Arrody ${ }^{1}$, Ruliando Hasea Purba ${ }^{2}$, Rina Ambar Dewanti ${ }^{2}$. \\ ${ }^{1}$ Program studi ilmu keolahragaan \\ ${ }^{2}$ Fakultas Ilmu Keolahragaan, Universitas Negeri Jakarta
}

\begin{abstract}
Abstrak. Penelitian ini bertujuan untuk menigkatkan kekuatan pada otot Flexor elbow pada mahasiswa ilmu keolahragaan Angskatan 2015 Universitas Negeri Jakarta dengan metode latihan kontraksi isotonik dan isometrik, serta sebagai pengetahuan untuk melihat seberapa efektifkah perubahan penngkatan kekuatan yang dihasilkan oleh dua model latihan tersebut. Penelitian ini dilaksanakan di Muscle Academy Gym, Universitas Negeri Jakarta dengan mengunakan metode kuantitatif dengan metode eksperimen. Pengambilan dan pengolahan data ini berlangsung dari Selasa, 26 April 2016 sampai Jum'at, 3 juni 2016. Penelitian diawali dengan mencari 1RM (Repetisi maksimal) biceps curl menggunakan biceps curl machine dengan sampel 20 orang yang terbagi menjadi dua kelompok yaitu, kelompok isotonik dan kelompok isometrik. Populasi pada penelitian ini adalah seluruh Mahasiswa Program Studi Ilmu Keolahragaan Universitas Negeri Jakarta Angkatan 2015 dan sampel pada penelitian ini adalah Mahasiswa Program Studi Ilmu Keolahragaan Universitas Negeri Jakarta Angkatan 2015 yang memenuhi kriteria. Terjadi peningkatan hasil kekuatan otot Flexor elbow setelah diberikan latihan dengan mengunakan metode isotonik dengan nilai t-hitung 14,28 Lebih besar dari nilai t-tabel 2,262. Selain itu, juga terjadi peningkatan hasil kekuatan otot flexor elbow setelah diberikan latihan dengan menggunakan metode isometrik dengan nilai thitung 8,5 lebih besar dari nilai t-tabel 2,262.
\end{abstract}

\section{Kata Kunci : Kekuatan Otot, Kontraksi Otot, Metode Latihan Penguatan}

\section{PENDAHULUAN}

Otot adalah "sebuah mesin, mampu mengubah energi kimia menjadi energi mekanik. Pada dasarnya otot bersifat unik. Belum ada mesin buatan yang memiliki ragam kemampuan layaknya otot. Otot Rangka membentuk bagian terbesar massa otot tubuh dan merupakan $40 \%$ berat badan total. Otot ini menempati dan menggerakkan tulang rangka, sesuai dengan namanya. 
Otot rangka pada umumnya dilekatkan pada tulang oleh tendon yang terbentuk dari kolagen.

Menurut sumber di atas, otot secara keseluran terdiri dari $40 \%$ sehingga merupakan variabel yang sangat mendukung dalam hal penelitian karena komposisinya cukup besar dan mungkin cukup mudah untuk dilihat perkembangannya dalam penelitian terutama dalam peningkatan kekuatan otot. Sehingga hasil yang nanti didapat membrikan data yang cukup akurat.

Otot Flexor sendi siku terdiri dari otot : biceps brachii, brachialis, brachioradialis. Otot Biceps brachii yang terdiri dari dua kepala yaitu caput longum yang berorigo di tuberculum supraglenoidale scapula dan caput breve yang berorigo di proc. Crocoideus berinsersio pada tuberositas radii. Sementara otot brachialis tulang humerus dan berinsersio pada tuberositas ulnae.

Otot flexor elbow penting dalam sebagian besar fungsional aktivitas karena memfleksikan sendi siku seperti mengangkat buku, membawa piring serta mengangkat beban seperti biceps curl.

Sasaran umum program latihan pada otot tertentu berguna untuk memperbaiki kinerja serta meningkatkan kekuatan yang merupakan suatu dari program latihan. Program latihan diberikan pada orang sehat misalnya seorang atlet berguna untuk meningkatkan performance otot untuk mencapai prestasi maksimal serta dapat mengurangi cedera yang mungkin disebabkan daya tahan otot yang lemah.
Pada dasarnya latihan isometrik adalah untuk terapi latihan sebagai metode untuk mencegah atropi dan meningkatkan hipertropi otot untuk meningkatkan kekuatan.

Metode latihan yang diberikan pada otot secara umum terdiri dari dua metode latihan yang berkaitan dengan model kontraksi otot yaitu : isotonik dan isometrik. Program latihan untuk isotonik berkaitan dengan menggerakkan beban sehingga menghasilkan tegangan sebaliknya isometrik yaitu kontraksi yang menghasilkan tegangan tanpa disertai pergerakan. Secara umum metode latihan yang menggunakan kontraksi isotonik berkaitan dengan peningkatan kekuatan dan pada kontraksi isometrik berkaitan pada peningkatan daya tahan.

Metode latihan dengan kontraksi otot isotonik maupun isometrik diatas telah menunjukkan kemampuan dalam peningkatan daya tahan dan kekuatan otot namun selalu ada pedebatan diantara keduanya manakah metode yang lebih baik terutama dalam peningkatan kekuatan otot serta peningkatan daya tahan otot.

Metode dari hasil latihan kontraksi isotonik maupun isometrik dapat memberikan pemahaman bagi saya selaku peneliti untuk menunjukkan seberapa besar hasil dari perbedaan peningkatan kekuatan otot yang ditimbulkan dari menggunakan dua metode tersebut. Hasil yang didapat berupa kekuatan otot dapat dihitiung dengan cara mencari 1RM ( repetisi maksimal ) dalam mengangkat beban, pengukuran 1RM pun merupakan suatu metode dalam latihan weight training 
dalam mencari satu repetisi angkatan maksimum.

$\begin{array}{llr} & \text { Metode latihan yang diberikan } \\ \text { adalah kepada } & \text { mahasiswa } & \text { ilmu } \\ \text { keolahragaan } & \text { angkatan } & 2015\end{array}$

Universitas Negeri Jakarta dikarenakan mahasiswa ini memiliki standar seleksi masuk yang baik terutama ketika seleksi masuk Fakultas Ilmu Keolahragaan serta menjadi dasar yang baik untuk melihat perkembangan otot yang terjadi.

Perlakuan yang diberikan pada otot flexor elbow dikarenakan otot tersebut mudah untuk diperhatikan serta gerakan yang diberikan pada flexor elbow tidaklah kompleks yaitu sebatas fleksi yaitu pendekatan antara tulang humerus dengan radius dan ulna.

Pengambilan data dengan otot flexor elbow sebagai variabel sangat menunjang bagi mahasiswa yang di berikan treatment dikarenakan kelompok otot flexor elbow merupakan otot antagonis dari extensor elbow yaitu triceps brachii dan merupakan otot yang jarang dilatih dengan latihan on body weigth berbeda dengan triceps brachii yang bisa dilatih dengan mudah seperti latihan push up ataupun triceps dips, sehingga cukup memberikan manfaat bagi sampel untuk memberikan keseimbangan antara kekuatan kelompok otot antagonis terutama di bagian lengan.

Tinjauan Pustaka. Menurut Ralph W. Stacy dan John A. Santolucito dalam moderncollege physiology . Otot adalah sebuah mesin, mampu mengubah energi kimia menjadi energi mekanik. Pada dasarnya otot bersifat cukup unik, belum ada mesin buatan yang memiliki ragam kemampuan layaknya otot.

Apabila tulang yang melekat pada otot dihubungkan dengan tulang lain melalui suatu persendian, kontraksi otot akan menggerakkan tulang tersebut. Otot penggerak disebut otot fleksor apabila kontraksi otot mendekatkan titik tengah kedua tulang yang berhubungan dengan gerakannya disebut fleksi. Apabila kontraksi otot rangka menjuhkan kedua tulang yang berhubungan maka otot tersebut disebut ekstensor dan gerakannya disebut ekstensi.

Sebagian besar persendian dalam tubuh memiliki kedua otot fleksor dan ekstensor, karena kontraksi otot dapat menarik tulang ke satu arah tetapi tidak dapat mendorongnya kembali. Pasangan otot fleksorekstensor disebut kelompok otot antagonis karena efeknya yang berlawanan. Dalam hal ini otot antagonis dapat digambarkan seperti biceps brachii dan triceps brachii dimana apabila gerakan fleksi siku digerakkan oleh otot biceps brachii sebagai fleksornya dan otot triceps brachii merupakan antagonisnya untuk berekstensi.

Setiap otot rangka di tubuh tidak memiliki kemampuan mendorong, otot rangka hanya dibekali kemampuan Tarik atau memendekkan otot sehingga terjadi gerakan pada persendian.

a) Kontraksi Otot Isometrik

Isometrik menurut bahasa tetap (iso) panjang (metric). Dengan kata lain kontraksi otot isometrik adalah kontraksi yang terjadi untuk 
meningkatkan tonus otot namun tidak disertai oleh pemanjangan ataupun pemendekan otot. Otot tidak memendek dikarenakan kontraksi terjadi ketika mengangkat beban melebihi kekuatan maksimum (di atas 100\%), seperti halnya mengangkat meja piano dengan sebelah tangan, kontraksi terjadi namun tidak menimbulkan pemendekan atau pemanjangan otot. Dengan kata lain kontraksi ini bersifat statis Meskipun tanpa pemendekan otot kontraksi otot isometrik dapat terjadi dikarenakan adanya elemen elastis, pada kontraksi isometrik, sarkomer memendek, tenaga dihimpun, tetapi elemen elastis meregang.

b) Kontraksi otot Isotonik

Kontraksi otot isotonik berarti tetap (iso) tegangan (tonic). Kontraksi otot istonik sering juga disebut degan kontraksi konsentrik adalah meningkatnya tonus/tegangan otot disertai dengan pergerakan sendi sehingga terjadi pemendekan otot (kebalikan dari kontraksi isometrik), kontraksi ini dapat diartikan juga sebagai pemendekan otot.

Hakikat Kekuatan. Kemampuan sistem neuromuskuler untuk menghasilkan tegangan internal untuk menguasai tegangan eksternal. Sedangkan menurut M. Sajoto, kekuatan (strength) adalah komponen kondisi fisik seseorang tentang kemampuannya dalam mempergunakan otot untuk menerima beban sewaktu kerja.
Tipe-tipe dari Kekuatan :

a. Absolute Strength

Kekuatan mutlak adalah gaya maksimum otot-otot yang dapat memaksakan untuk tindakan tertentu. Biasanya tipe kekuatan diukur dengandari segi jumlah berat diangkat (1RM).

b. Relative Strength

Kekuatan relatif berkaitan dengan upaya maksimum dalam hubungan dengan berat badan Anda. Karena terhubung dengan berat badan Anda, klasifikasi ini mendukung orangorang yang berat badan rendah. Angkat besi Olimpiade adalah contoh di sini, karena berat para pesaingdiperhitungkan dalamtiebreak. Jika dua atlet angkat besi berakhir menyelesaikan jumlah angkatan sama berat, pemenangnya adalah orang yang memiliki bobot kurang.

c. Power ( Speed Strength)

Power adalah seberapa cepat kita menggunakan kekuatan. Dari sudut pandang teknik fisika, daya adalah laju dalam melakukan pekerjaan (didefinisikan sebagai gaya $\mathrm{x}$ jarak). Contohnya adalah lompat jauh.

d. Strength Endurance

Daya tahan kekuatan adalah bentuk spesifik dari kekuatan yang ditampilkan dalam kegiatan yang membutuhkan durasi yang relatif lama tegangan otot dengan penurunan minimal dalam hal efisiensi.

Metode Latihan Penguatan.Pada penelitian kali ini metode yang digunakan dalam latihan penguatan adalah dengan bentuk latihan isotonik dan latihan isometrik. 


\section{a) Metode latihan isotonik}

Program latihan penguatan yang dianjurkan oleh DeLorme dan Watkins pada tahun 1948. Dalam programnya menggunakan 10 repetisi maksimal (10RM) dengan kata lain beban maksimal bisa diangkat sebanyak 10 kali. Untuk setiap kelompok otot yang dilatih, program latihan terdiri sebanyak 30 repetisi per sesi latihan terbagi dalam tiga set 10 repetisi setiap set, sebagai berikut :

\section{Tabel 1. Metode latihan Isotonik De Lorme dan Watkins}

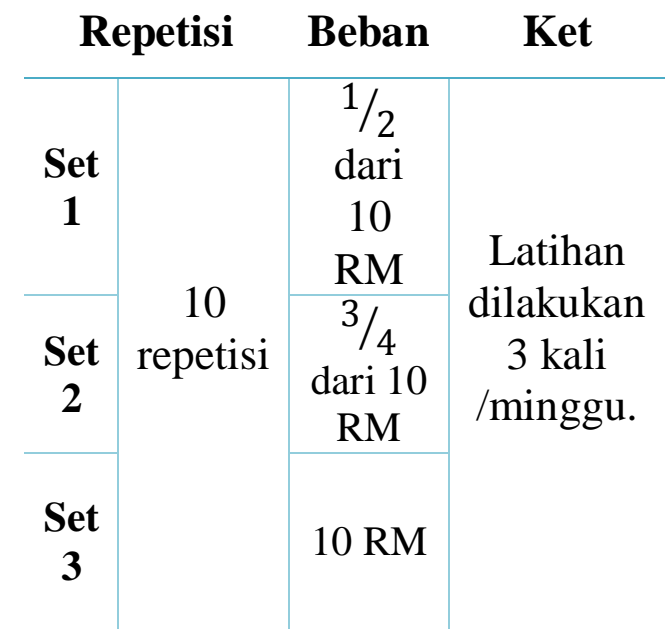

Beberapa perhatian secara umum hasil dari program latihan ini mungkin dapat terjamin karena subjek menampilkan 18 set dalam 1 RM selama setiap latihan. Ini bisa dilihat dengan angka yang tidak biasa dalam satu set. Faktanya ketika 3 set dari 6 sampai 8 RM yang kita pelajari, subjek memperoleh hasil yang kekuatan serupa mengangkat dua hari dibandingkan dengan tiga hari per minggu. sekarang lazim untuk merekomendasikan bahwa pra pelatihan dilakukan 3 atau 4 hari per minggu bergantian daripada setiap hari berturut-turut.

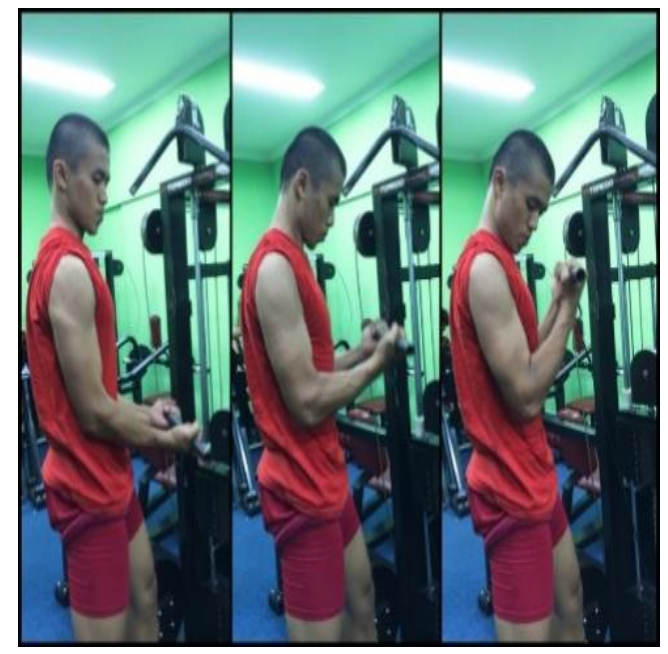

Gambar 1. Latihan Isotonik Low Pulley Biceps Curl.

Dari Gambar di atas dapat dipahami posisi awal di mulai dari posisi fleksi siku dengan sudut sebesar $120^{\circ}$ lalu berlanjut sampai dengan posisi fleksi maksimal dengan membentuk sudut $60^{\circ}$. Latihan dilakukan dengan kecepatan sedang. Dilakukan selama 3 kali /Minggu selama 4 minggu. Dengan menguji tes awal 1 RM dan diakhiri dengan tes akhir 1 RM dengan Biceps curl Machine.

Secara singkat metode latihan De lorme \& Watkins adalah dengan model latihan peningkatan kekuatan dengan cara melawan beban dari rendah - ketinggi yaitu dari 1/2 (10RM), 3/4 (10RM), sampai maksimal dari $10 \mathrm{RM}$, latihan ini memiliki dosis 3-5 kali seminggu menurut penelitian dari De Lorme \& Watkins, dan pada penelitian kali ini menggunakan dosis 3 kali seminggu. 
Tabel 2. Hubungan antara intensitas latihan dengan periode istirahat.

\section{Exercise Intensity and \\ Recommended Rest Periods ( Kraemer 2003 )}

\begin{tabular}{|c|c|}
\hline Intensity & Length of Rest \\
\hline $\begin{array}{l}>13 . \mathrm{RM} \sim<65 \% \\
1 . \mathrm{RM}\end{array}$ & $<1$ Minute \\
\hline $\begin{array}{l}\text { 11.RM to } 13 . R M ~ \\
65 \text { to } 74 \% 1 . R M\end{array}$ & 1-2 Minute \\
\hline $\begin{array}{l}\text { 8.RM to 10.RM } \\
\sim 75-80 \% 1 . R M\end{array}$ & 2-3 Minute \\
\hline $\begin{array}{l}\text { 5.RM to 7.RM } \\
76-87 \% \text { 1.RM }\end{array}$ & 3-5 Minute \\
\hline $\begin{array}{c}<5 . \mathrm{RM} \sim>87 \% \\
1 . \mathrm{RM}\end{array}$ & $>5$ Minute \\
\hline
\end{tabular}

Dari tabel di atas merupakan contoh dari hubungan antara intensitas latihan yang diberikan kepada pasien terhadap lamanya durasi istirahat dari set pertama ke set berikutnya.

\section{b) Metode Latihan Isotonik}

Pada tahun 1953, Hettinger dan Muller melaporkan bahwa orang-orang menghasilkan peningkatan kekuatan yang signifikan dalam menggunakan latihan isometric. Studi asli mereka mengungkapkan bahwa kekuatan maksimal dapat meningkat pada laju sekitar 5\% /minggu hanya dengan kontraktor isometrik kelompok otot selama 6 detik pada 2/3 ketegangan maksimal sekali sehari 5 hari per minggu dengan setiap sesi latihan dilakukan 5-10 kontraksi maksimal masing-masing 5 detik. Tipe latihan latihan ini menjadi popular pada sekitar akhir tahun 1950 dan awal tahun 1960an karena latihan ini bisa di lakukan dimanapun dan kapanpun dengan sedikit peralatan. Pada umumnya latihan isometrik digunakan untuk rehabilitasi dan melawan atrophy otot. Dengan demikian Untuk meningkatkan kekuatan secara keseluruhan ROM, latihan membutuhkan perlakuan pada angka sudut sendi yang berbeda. (ex., $30^{\circ}, 60^{\circ}$, $90^{\circ}, 120^{\circ}, 180^{\circ}$ dari fleksi lutut). Setelah penelitian lebih jauh, Hettinger dan Muller memodifikasi resep original latihan mereka, lihat gambar di bawah:

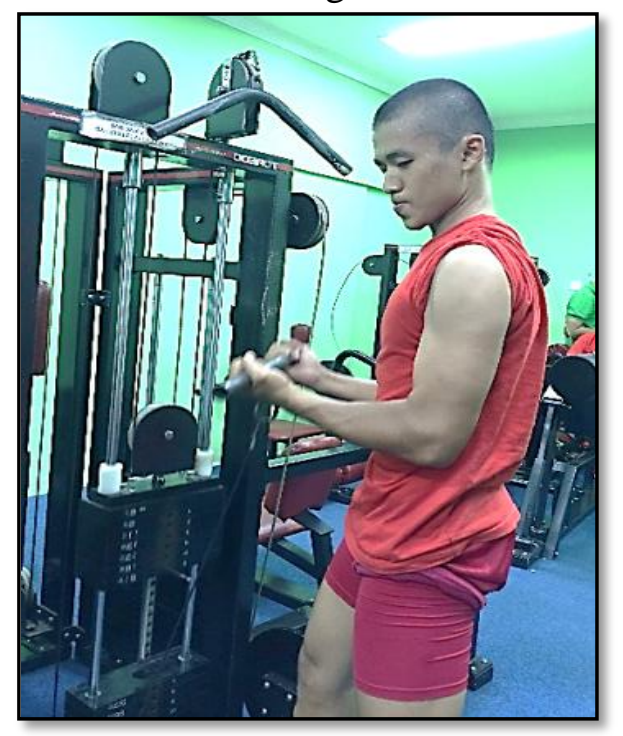

Gambar 2. Latihan Isometrik Low Pulley Biceps Curl

Dari gambar di atas latihan isometrik dilakukan dengan posisi sudut fleksi siku $90^{\circ}$, pasien melakukannya dengan cara menahan beban selama 5 detik kontraksi maksimum beban $100 \%$, istirahat antar repetisi 6 detik, dilakukan 5-10 repetisi selama 4 minggu. Dilakukan test awal 1 RM untuk mengetahui kekuatan maksimal dan sebagai data awal untuk melakukan program latihan lalu dilakukan test akhir untuk melihat hasil latihan dengan cara 1 RM. Secara singkat latihan kontraksi otot isometrik merupakan suatu latihan tahanan beban secara konstan tanpa menimbulkan gerakan atau disebut juga latihan statis, 
umumnya menurut Hettinger dan Muller latihan ini bertujuan untuk rehabilitasi dalam menghindari atrophy otot dan meningkatkan hypertrophy otot.

\section{KERANGKA BERPIKIR}

Kontraksi isotonik dan isometrik tidak dapat dipisahkan dalam proses terjadinya karena apabila melakukan kontraksi isotonik pasti diawali oleh kontraksi isometrik sebagai awalan kontraksi, ketika kontraksi isometrik terjadi peningkatan tonus otot tanpa diikuti pergeseran sendi sehingga terjadi pelebaran pembuluh darah serta peningkatan tekanan darah, oleh sebab itu latihan dengan model isometrik tidak dianjurkan bagi pasien yang mengalami hipertensi, pada kontraksi isotonik terjadi metabolisme aerobik karena bersifat berulang-ulang yang dapat menyebabkan penurunan kadar lemak. Tujuan umum latihan penguatan otot adalah untuk:

1. Mengembalikan fungsional otot apabila terjadi atrofi otot

2. Meningkatkan kekuatan otot dalam olahraga prestasi

3. Mencegah cedera karena kelemahan otot

4. Meningkatkan kualitas fungsional otot dalam bergerak

Untuk mencapai 4 poin di atas diperlukan sebuah latihan penguatan yang dalam hal ini adalah dengan cara metode latihan isotonik dan latihan isometrik, metode ini berdasarkan dari bagaimana otot berkontraksi, pemilihan metode ini bertujuan untuk mengetahui seberapa efektifkah pengaruh metode tersebut dalam peningkatan hipertropi otot serta peningkatan kekuatan yang dimiliki oleh otot. Setiap metode latihan baik itu menggunakan metode isotonik maupun isometrik memiliki kelebihan dan kekurangan namun tujuan dari penelitian ini adalah untuk melihat serta menganalisis seberapa besarkah perbedaan yang dihasilkan dari metode tersebut.

\section{METODE}

Metode penelitian yang digunakan dalam penelitian ini adalah metode“"Eksperimen".Penelitian eksperiman bertujuan untuk menyelidiki kemungkinan saling hubungan sebab akibat dengan cara mengadakan perlakuan kepada satu atau lebih kelompok eksperimen, kemudian hasilnya di bandingkan dengan kelompok yang tidak diberikan perlakuan. Metode yang akan digunakan adalah metode eksperimen yaitu dengan desain penelitian menggunakan Pre-Test dan Post-Test Two Group yaitu untuk mengetahui pengaruh variabel bebas terhadap variable terikat.

Metode eksperimen merupakan bagian dari metode kuantitatif, dan memiliki ciri khas tersendiri terutama dengan adanya kelompok kontrol.

Adapun yang menjadi variabel bebas adalah metode latihan otot isotonik dan latihan otot isometrik terhadap peningkatan kekuatan otot flexor elbow pada mahasiswa program studi Ilmu Keolahragaan Universitas Negeri Jakarta Angkatan 2015.

Instrumen Penelitian. Penelitian ini menggunakan instrumen yang digunakan adalah tes awal dengan 
menggunakan 1RM biceps curl untuk mengukur kekuatan oto flexor elbow.

Tekhnik Pengumpulan Data. Dalam pengambilan data diambil populasi mahasiswa ilmi keolahragaan berjumlah 80 orang serta ditarik dengan robabilii sampling sehingga didapat 20 orang yang nantinya akan dibagi menjadi 2 kelompok secara acak. Kelompok pertama menggunakan metode isotonic dan kelompok kedua menggunakan metode isometrik low pulley biceps curl.

Pelaksanaan untuk mendapatkan data adalah sebagai berikut :

1. Melakukan tes awal 1RM untuk semua sampel yang telah dipilih menggunakan Biceps curl machine untuk mengukur kekuatan otot.

2. Setelah dilakukan tes awal maka sampel dibagi menjadi dua kelomok yang masing-masing kelompok terdiri dari 10 orang. Pembagian kelompok dilakukan dengan menggunakan teknik random (acak).

3. Kelompok pertama akan menjalani latihan otot isotonik menggunakan metode latihan De Lorme dan Watkins. Sedangkan kelompok kedua akan menjalani latihan otot isometrik menggunakan metode Muller dan Hetinger. Proses latihan dilakukan 3 - 4 kali seminggu dalam waktu 1 bulan 1 minggu.

4. Pada pertemuan terakhir akan dilakukan tes akhir 1RM menggunakan alat yang sama yaitu Biceps curl machine.

\section{HASIL DAN PEMBAHASAN Deskripsi Data}

1. Data hasil tes metode latihan Kontraksi Otot Isotonik.

Data yang akan di analisa dalama penelitian ini diambil dari tes awal 1 RM sebelum diberikan proses perlakuan latihan Kekuatan dengan menggunakan metode Kontraksi Isotonik dan tes akhir 1RM setelah diberikan perlakuan latihan kekuatan dengan metode Kontraksi Isotonik. Adapun dengan data tersebut adalah sebagai berikut.

a. Data tes awal kekuatan kelompok metode Isotonik $\left(\mathrm{X}_{1}\right)$ hasilnya memiliki tes terkuat $26 \mathrm{~kg}$ dan tes terendah $18.5 \mathrm{~kg}$, dengan rata-rata $\left(\mathrm{X}_{1}\right)=23.25 \mathrm{~kg}$, simpang baku $\left(\mathrm{Sx}_{1}\right)$ $=2.49$ dan standar kesalahan mean $\left(\mathrm{SEmx}_{1}\right)=0,83$.

Data tes akhir kekuatan kelompok metode Isotonik $\left(\mathrm{X}_{2}\right)$ hasilnya memiliki tes terkuat $29.75 \mathrm{~kg}$ dan tes terendah $21 \mathrm{~kg}$, dengan rata-rata $\left(\mathrm{X}_{2}\right)=$ $26.25 \mathrm{~kg}$, simpang baku $\left(\mathrm{SX}_{2}\right)=2.75$ dan standar kesalahan mean $\left(\mathrm{SEmx}_{2}\right)=$ 0,92 .

Tabel 3. Distribusi Frekuensi Tes Awal Kelompok kontraksi isotonik

\begin{tabular}{l|c|c|c|c}
\multirow{2}{*}{ No } & Kelas & Nilai & \multicolumn{2}{|c}{ Frekuensi } \\
\cline { 4 - 5 } & Interval & Tengah & Absolut & Relatif \\
\hline 1 & $18,5-$ & 19,43 & 1 & $10 \%$ \\
& 20,37 & & & \\
\hline 2 & $20,38-$ & 21,31 & 2 & $10 \%$ \\
& 22,25 & & & \\
\hline 3 & $22,26-$ & 23,19 & 4 & $40 \%$ \\
& 24,13 & & & \\
\hline 4 & $24,14-$ & 25,07 & 3 & $30 \%$ \\
& 26 & & & $100 \%$
\end{tabular}


Tabel 4. Distribusi Frekuensi Tes Akhir Kelompok Kontraksi Isotonik

\begin{tabular}{|c|c|c|c|c|}
\hline \multirow{2}{*}{ No } & \multirow{2}{*}{$\begin{array}{l}\text { Kelas } \\
\text { Interval }\end{array}$} & \multirow{2}{*}{$\begin{array}{l}\text { Nilai } \\
\text { Tengah }\end{array}$} & \multicolumn{2}{|c|}{ Frekuensi } \\
\hline & & & Absolut & Relatif \\
\hline 1 & $\begin{array}{c}21- \\
23.19\end{array}$ & 22,09 & 1 & $10 \%$ \\
\hline 2 & $\begin{array}{l}23.2- \\
25.39\end{array}$ & 24,3 & 2 & $20 \%$ \\
\hline 3 & $\begin{array}{l}25.4- \\
27.59 \\
\end{array}$ & 26,5 & 4 & $40 \%$ \\
\hline 4 & $\begin{array}{l}27.6- \\
29.79\end{array}$ & 28,69 & 3 & $30 \%$ \\
\hline & Jumla & & 10 & $100 \%$ \\
\hline
\end{tabular}

Data hasil tes metode latihan kontraksi isometric. Data yang akan di analisa dalam penelitian ini diambil dari tes awal sebelum diberikan prosess perlakuan latihan kekuatan dengan menggunakan metode isometrik dan tes akhir setelah diberikan perlakuan latihan kelincahan dengan metode isometrik. Adapun dengan data tersebut adalah sebagai berikut.

a. Data tes awal kekuatan kelompok metode isometrik $\left(\mathrm{Y}_{1}\right)$ hasilnya memiliki tes terkuat $33.5 \mathrm{Kg}$ dan tes terendah $18.5 \mathrm{Kg}$, dengan rata-rata $\left(\mathrm{Y}_{1}\right)=25.25 \mathrm{Kg}$, simpang baku $\left(\mathrm{SY}_{1}\right)=4.42$ dan standar kesalahan mean $\left(\mathrm{SEmx}_{1}\right)=1.47$.

Data tes akhir kekuatan kelompok metode isometric $\left(\mathrm{Y}_{2}\right)$ hasilnya memiliki tes terkuat $34.75 \mathrm{Kg}$ dan tes terendah $21 \mathrm{Kg}$, dengan rata-rata $\left(\mathrm{Y}_{2}\right)=$ 27.12 simpang baku $\left(\mathrm{SY}_{2}\right)=4.1$ dan standar kesalahan mean $\left(\mathrm{SEMy}_{2}\right)=$ 1.37 .
Tabel 5. Distribusi Frekuensi Tes Awal Kelompok Kontraksi Isometrik

\begin{tabular}{c|c|c|c|c}
\multirow{2}{*}{ No } & Kelas & Nilai & \multicolumn{2}{c}{ Frekuensi } \\
\cline { 4 - 5 } & Interval & Tengah & Absolut & Relatif \\
\hline 1 & $\begin{array}{c}18.5- \\
22.25\end{array}$ & 20,37 & 2 & $20 \%$ \\
\hline 2 & $\begin{array}{c}22.26- \\
26.01\end{array}$ & 24,13 & 6 & $60 \%$ \\
\hline 3 & $\begin{array}{c}26.02- \\
29.77\end{array}$ & 27,89 & 0 & $0 \%$ \\
\hline 4 & $\begin{array}{c}29.78- \\
33.53\end{array}$ & 31,65 & 2 & $20 \%$ \\
\hline \multicolumn{3}{|c|}{ Jumlah } & 10 & $100 \%$
\end{tabular}

Tabel 6. Distribusi Frekuensi Tes Akhir Kelompok Kontraksi Isometrik

\begin{tabular}{l|c|c|c|c}
\multirow{2}{*}{ No } & Kelas & Nilai & \multicolumn{2}{c}{ Frekuensi } \\
\cline { 4 - 5 } & Interval & Tengah & Absolut & Relatif \\
\hline 1 & $21-$ & 22,72 & 2 & $20 \%$ \\
& 24.44 & & & \\
\hline 2 & $24.45-$ & 26.17 & 4 & $40 \%$ \\
& 27.89 & & & \\
\hline 3 & $27.9-$ & 29,62 & 2 & $20 \%$ \\
& 31.34 & & & \\
\hline 4 & $31.35-$ & 33,07 & 2 & $20 \%$ \\
\hline \multicolumn{3}{|c|}{ Jumlah } & 10 & $100 \%$
\end{tabular}

\section{PENUTUP}

Kesimpulan. Berdasarkan masalah yang dikemukakan serta didukung deskripsi kerangka teori dan kerangka berfikir serta analisis data, maka hasil terebut dapat disimpulkan bahwa :

1. Terdapat peningkatan kekuatan pada otot flexor elbow pada sampel yang menggunakan metode latihan kontraksi otot isotonik pada mahasiswa ilmu keolahragaan Universitas Negeri Jakarta Angkatan 2015.

2. Terdapat Peningkatan kekuatan pada otot flexor elbow pada sampel 
yang menggunakan metode latihan kontraksi otot isometrik pada mahasiswa ilmu keolahragaan Universitas Negeri Jakarta Angkatan 2015.

3. Dari hasil penelitian yang telah dilakukan dapat dibandingkan bahwa latihan dengan kontraksi isotonik lebih baik dalam hal peningkatan kekutan dari pada dengan latihan isometrik pada otot flexor elbow mahasiswa Ilmu Keolahragaan Universitas Negeri Jakarta Angkatan 2015.

Saran. Berdasarkan hasil penelitian dan kesimpulan yang didapat dari penelitian tentang perbandingan metode latihan kontraksi isotonik dan isometrik terhadap peningkatan otot flexor elbow pada mahasiswa ilmu keolahragaan Universitas Negeri Jakarta angkatan 2015, yaitu:

1. Diusahakan menggunakan sampel yang cukup sering berolahraga karena metode delorme dan isometric muller menggunakan beban maksimum, dengan menggunakan sampel yang suka berolahraga dapat mengurangi kelelahan otot.

2. Dalam mencari $1 \mathrm{RM}$ dan 10 RM diusahakan harus diteliti dari koreksi gerakan samapai peningkatan beban yang diberikan sehingga hasilnya pun tepat.

3. Pada latihan isotonik menggunakan beban $1 / 2,3 / 4$, dan 1 dari 10 RM diharapkan peneliti dapat menghitung pembagian beban secara tepat sehingga hasil peningkatan bebannya pun tepat. dan pada latihan isometrik harap sangat diperhatikan posisi sudut yang diberikan ketika melakukan latihan misalnya $90^{\circ}$ pada fleksi biceps curl.

4. Selalu mengikuti aturan yang dijelaskan pada buku pedoman atau referensi sehingga mengurangi kesalahan dalam mendapatkan hasil penelitian.

5. Penelitian ini terdapat kelemahan pada pembagian kelompok sampel, diusahakan untuk peneliti berikutnya untuk menguji $\mathrm{T}$ dahulu sebelum pembagian kelompok antara kelompok latihan isotonik dan isometrik sehingga mengurangi bias dan menyamarkan kekuatan awal sampel.

6. Penelitian ini memiliki hasil bahwa metode isotonik lebih baik dalam peningkatan kekuatan daripada isometrik, namun ada beberapa sumber yang tidak setuju terhadap teori tersebut sehingga untuk penelitian berikutnya diharapakan untuk lebih memperkuat teori yang mendukung dalam hal perbandingan latihan kekuatan antara kontraksi isotonik dan isometrik.

\section{DAFTAR RUJUKAN}

Bompa, Tudor O. Theory and Methodology of Training, terjemahan, 1992. 
Buchari Alma, Metode dan Teknik Menyusun Tesis, Bandung : Alfabeta.

Harsono. Ilmu Coaching. Jakarta : Pusat Olahraga Koni Pusat, 2010.

Elaine N. Marieb, R.N., Katja Hoehn. Anatomy\&Physiology Ed.5. USA : Pearson, 2014.

Frederic delavier. Strength Training Anatomy Ed.2, Paris : Edition Vigot, 2006.

Heyward, Vivian H. Advance Fitness Assessment and exercise prescription USA : Vivian $\mathrm{H}$. Heyward, 2010.

Kountur, Ronny. Metode Penelitian untuk Penulisan Skripsi dan Tesis. Jakarta : PPM, 2007.

Mescher, Anthony L. Histologi Dasar Junqueira: Teks \& Atlas ed. 12, Jakarta : EGC, 2011.

Michael A. Clark, Scott C. Laurett, NASM's Essential of Sports Performance Training, USA, : Lippincot Williams \& Wilkins, 2010.

Notoadmojo, Soekidjo. Metodologi Penelitian kesehatan Ed. Revisi, Jakarta, :Rineka Cipta, 2012.

Paulsen, Frederich \& Jens Waschke. Sobotta : Atlas Anatomi Manusia ed. 23 jilid 1, Jakarta : EGC, 2010. - Sobotta : Atlas Anatomi Manusia ed. 23 buku tabel otot, Jakarta : EGC, 2010.

Robergs, Robert A. \& Steven J. Keteyian. Fundamentals of Exercise Physiology : For Fitness, Performance, and Health. Inggris : McGraw Hill, 2003.
Sajoto. Peningkatan dan Pembinaan Kekuatan Kondisi Fisik dalam Olahraga. Dahara Prize.

Sherwood, Lauralee. Fisiologi Manusia - Dari Sel ke Sistem ed.6, Jakarta : EGC, 2011.

Silverthorn, Dee Unglaub. Fisiologi Manusia : Sebuah Pendekatan Terintegrasi ed.6. Jakarta : EGC, 2013.

Sudjiono, Anas. Pengantar Statistik Pendidikan Jakarta: P.T. Raja Grafindo persada, 2003.

Sukadiyanto. \& Dangsina Muluk. Pengantar Teori dan Metodologi Melatih Fisik. Bandung : Lubuk Agung, 2011. Widiastuti. (2011). Tes dan Pengukuran Olahraga. Jakarta : PT. Bumi Timur Jaya.

Grandjean (1988)

http://www.landasanteori.com/2 015/09/pengertiankelelahandefinisi-jenis.html, diakses 29 Maret 2016, Pukul 11.00

ttps://gmb.io/strength-training/ diakses 6 April 2016, Pukul 22.52. 